\title{
Demographic and radiologic characteristics of patients with an accessory spleen: An octennial experience
}

\author{
Aydin Bora' ${ }^{1}$, Alpaslan Yavuz ${ }^{1}$, Muhammed Alpaslan ${ }^{1}$, Güneş Açıkgöz ${ }^{2}$, Mehmet Deniz Bulut ${ }^{1}$, Haliı \\ Arslan $^{3}$ \\ 1. Yüzüncü Yil University, Faculty of Medicine, Department of Radiology, Van, Turkey. 2. Mustafa Kemal University, \\ Vocational School of Health Services, Hatay, Turkey. 3. Yildirim Beyazit University, Faculty of Medicine, Department of \\ Radiology, Ankara, Turkey.
}

Correspondence: Aydın Bora. Address: Yüzüncü Yil University Hospital, Campus, Ercis Yolu, 65100, Van, Turkey. Email: abora6565@hotmail.com

Received: August 21, 2014

DOI: $10.5430 /$ ijdi.v2n1p10

Accepted: September 4, $2014 \quad$ Online Published: September 19, 2014

URL: http://dx.doi.org/10.5430/ijdi.v2n1p10

\section{Abstract}

Purpose: Spare spleen or accessory spleen may develop as a result of the rupture of the spleen after an injury or as a result of an anomaly. The purpose of this study was to describe the prevalence and Computerized Tomography features of the accessory spleen.

Material and Methods: Results obtained from patients who were referred to our clinic between January 2005 and January 2013, and who underwent a Computerized Tomography scan due to a clinical indication were investigated according to age, gender, presence and location of an accessory spleen and valuated as percentages.

Results: Accessory spleen was found in a total of 1693 patients whose ages ranged from 4-99 years. When accessory spleen was evaluated by location, we detected a total number of $801(47.73 \%)$ patients, mostly with a splenic hilum. Patients with an accessory spleen were also evaluated according to gender; a total number of 808 (47.73\%) patients were females and 885 (52.27\%) were males. However, when accessory spleen was evaluated by age, we found that there were a total number of 383 patients, who were mostly 40-49 years old, ranked in the second row, while 314 patients were 50-59 years old.

Conclusion: The investigation of an accessory spleen is very important, especially during the preoperative and postoperative terms, to prevent relapse and for therapy planning. It is essential to maintain periodic radiological follow-ups regarding the size and morphology of an accessory spleen.

\section{Keywords}

Spleen, Computerized Tomography, Splenectomy

\section{Introduction}

Accessory spleen can be seen in more than $10 \%$ of the normal population. Accessory spleen may develop as a result of the rupture of the spleen after an injury or as a result of an anomaly. It is considered to be a finding with no clinic importance 
as it is usually detected as a result of a coincidence. Accessory spleen is best detected by Computerized Tomography (CT) scanning and can be seen as round masses with regular borders. Commonly, the average size of an accessory spleen in CT scans is approximately $1 \mathrm{~cm}$ although this value may vary between a few $\mathrm{mm}$ and $2 \mathrm{~cm}-3 \mathrm{~cm}{ }^{[1-5]}$.

The spleen can be immediately noticed in every abdominal CT scan and CT accessory spleen scanning can provide a simple, rapid and better alternative to evaluate the spleen of a patient ${ }^{[3]}$. Helical, volumetric CT scanning with bolus injection of contrast material is considered the state-of-the-art imaging modality for evaluation of the spleen, since other imaging methods, for example Ultrasound, have a low specificity ${ }^{[1-10]}$.

Accessory spleen is primarily found in the splenic hilum (75\%) ${ }^{[6]}$, but may develop at any location in the abdomen. In other words, accessory spleen can be seen in various locations, at the diaphragm and even the scrotum and frequently can be detected beside the primary organ or alongside the splenic veins or ligaments ${ }^{[7]}$. An accessory spleen can consist of single or multiple masses; however, it is very rare to detect more than six accessory spleens ${ }^{[2]}$. The purpose of this study was to describe the prevalence and $\mathrm{CT}$ features of the accessory spleen.

\section{Material and method}

Results obtained from patients who were referred to Department of Radiology, Yüzüncü Yil University between January 2005 and January 2013, and who underwent a CT scan due to a clinical indication were retrospectively investigated according to age, gender, presence and location of an accessory spleen and valuated as percentage. All CT scans were examined by four radiologists.

From 2004-2013, abdominal CT scans of 37600 patients were performed. Scans from 2004-2012 were conducted on a 4-detector, multi-sectional computerized tomography scanner (Somatom Sensation 4, Siemens Medical Solutions), and those from 2012-2013 were performed on a 16-detector, multi-sectional computerized tomography scanner (Somatom Emotion 16-slice; CT2012E- Siemens AG Berlin and München-Germany). Unenhanced and contrast-enhanced images were obtained using different imaging parameters. These parameters were 120-130 (Kv), 80-120 (Ef-Mass), $0.6 \mathrm{sec}$ (Rotation time), $16 \mathrm{~mm} \times 1.2 \mathrm{~mm}$ (Acquisition), 1, $2 \mathrm{~mm}$ (Slice collimation), 5.0-3.0 (Slice width), 0.80 (Pitch factor), 5.0 $\mathrm{mm}$ (Increment) and $512 \times 512$ (Matrix) were used. It was found that $90 \%$ of patients undergoing contrast enhanced abdominal CT scans had accessory spleens and $10 \%$ of patients undergoing unenhanced abdominal CT scans had accessory spleens.

Dilute osmolak (lactulose, Biofarma) was administered orally to opacity the gastrointestinal tract. Contrast-enhanced images were obtained 50-70 sec after IV administration of $120 \mathrm{ml}$ of ionic iodinated contrast material, iodiksanol (Visipaque $320 \mathrm{mg} / 100 \mathrm{ml}$, Opakim) using a power injector at a rate of $2 \mathrm{ml} / \mathrm{sec}$.

\section{Results}

After contrasted (see Figure 1a) and non-contrasted (see Figure 1b) scanning processes, we determined accessory spleen in a total number of 1693 patients whose ages ranged from 4-99 years of age. When accessory spleens were evaluated according their location in the spleen (according to the spleen), we determined a total number of 801 (47.73\%) patients with an accessory spleen primarily located at the splenic hilum, while accessory spleen was secondarily located in the spleen inferior (see Figure 2) in a total number of 347 (20.5\%) patients (see Table 1). When patients with an accessory spleen were also evaluated according to gender, a total number of $808(47.73 \%)$ patients were found to be females and 885 $(52.27 \%)$ were males (see Table 2). The number of female and male patients was similar. 
Accessory spleen usually appeared as a vast number of regularly shaped, rounded lesions in CT scans of our patients. Moreover, the sizes of these lesions varied. Based on the findings, the size of accessory spleens may vary between $7 \mathrm{~mm}$ and $3.3 \mathrm{~cm}$.

When accessory spleens were evaluated by patients' ages, we found a total number of 383 patients from $40-49$ years old and ranked in the second row, and 314 patients were 50-59 years old (see Table 3).

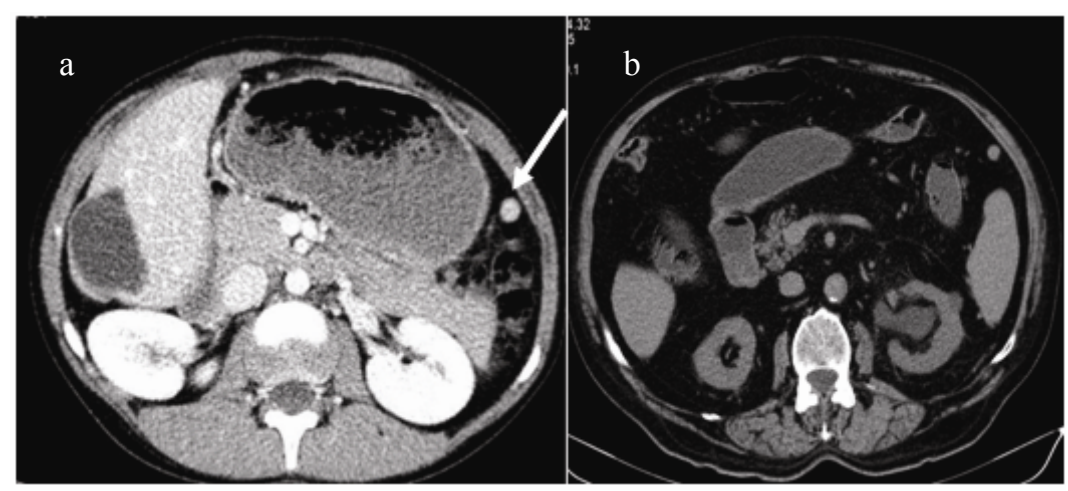

Figure 1. a. Accessory spleen can be monitored in contrasted axial CT image b. Accessory spleen can be monitored adjuvant to superior in non-contrasted axial CT image

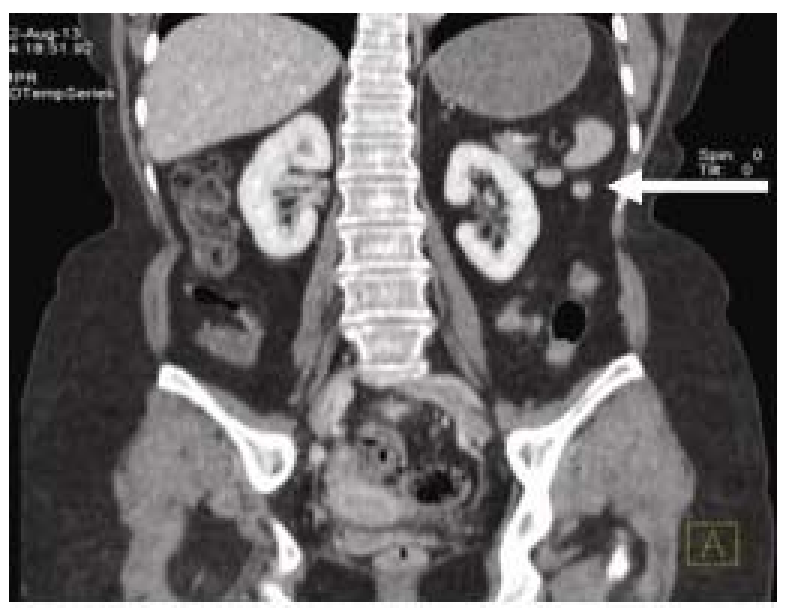

Figure 2. Accessory spleen can be monitored at the spleen inferior in a contrasted coronal computerized tomography image

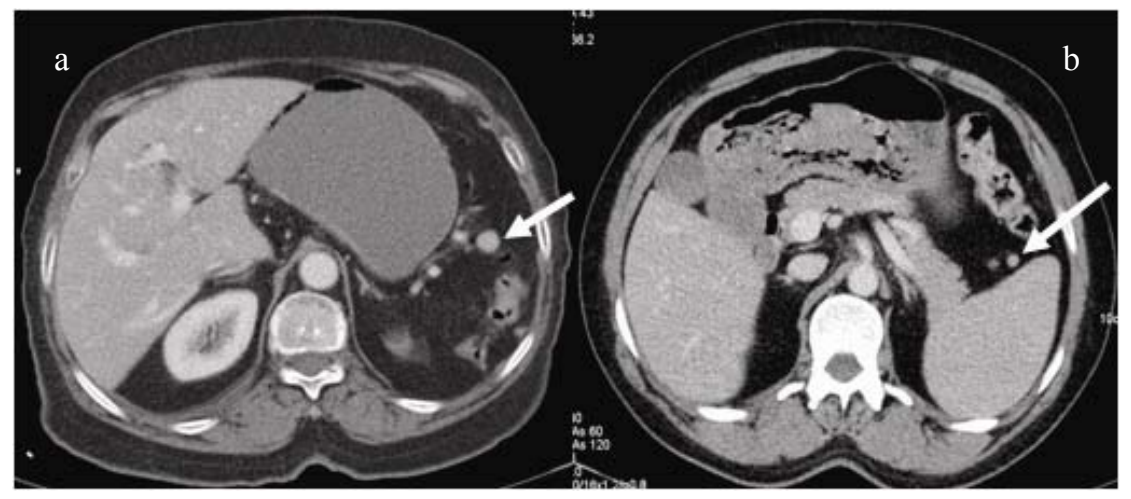

Figure 3. Contrasted axial CT: a. Accessory spleen is monitored b. Accessory spleen can be monitored adjuvant to medial of spleen 
Table 1. Distribution of accessory spleen patients according to the location in spleen

\begin{tabular}{lll}
\hline \multirow{2}{*}{ Location } & \multicolumn{2}{l}{ Accessory Spleen $(+)$} \\
\cline { 2 - 3 } & Number $(\mathbf{n})$ & $\%$ \\
\hline Hilum & 801 & 47.31 \\
İnferior & 347 & 20.50 \\
Anterior & 351 & 20.73 \\
Posterior & 42 & 2.48 \\
Superior & 60 & 3.54 \\
Lateral & 47 & 2.78 \\
Hilum and İnferior & 8 & 0.47 \\
Hilum and Anterior & 21 & 1.24 \\
Anterior and Posterior & 4 & 0.24 \\
Medial and Anterior & 6 & 0.35 \\
Lateral and İnferior & 4 & 0.24 \\
Superior and inferior & 2 & 0.12 \\
Total & 1693 & 100 \\
\hline
\end{tabular}

Table 2. Distribution of accessory spleen patients according to gender

\begin{tabular}{|c|c|c|c|c|c|}
\hline \multirow{2}{*}{ Location } & \multicolumn{2}{|c|}{ Male } & \multicolumn{2}{|c|}{ Female } & \multirow{2}{*}{$\frac{\text { Total }}{\mathrm{n}}$} \\
\hline & $\mathbf{n}$ & $\%$ & $\mathbf{n}$ & $\%$ & \\
\hline Hilum & 438 & 25.87 & 363 & 21.44 & 801 \\
\hline İnferior & 155 & 9.16 & 192 & 11.34 & 347 \\
\hline Anterior & 175 & 10.34 & 176 & 10.39 & 351 \\
\hline Posterior & 24 & 1.41 & 18 & 1.06 & 42 \\
\hline Superior & 37 & 2.19 & 23 & 1.36 & 60 \\
\hline Lateral & 35 & 2.07 & 12 & 0.71 & 47 \\
\hline Hilum and İnferior & 5 & 0.30 & 3 & 0.17 & 8 \\
\hline Hilum and Anterior & 2 & 0.12 & 19 & 1.12 & 21 \\
\hline Anterior and Posterior & 4 & 0.24 & - & - & 4 \\
\hline Medial and Anterior & 6 & 0.35 & - & - & 6 \\
\hline Lateral and İnferior & 4 & 0.24 & - & - & 4 \\
\hline Superior and inferior & - & & 2 & 0.12 & 2 \\
\hline Total & 885 & 52.27 & 808 & 47.73 & 1693 \\
\hline
\end{tabular}


Table 3. Distribution of accessory spleen patients according to age

\begin{tabular}{|c|c|c|c|c|c|c|c|c|c|c|c|c|c|}
\hline \multirow{2}{*}{ Age } & \multicolumn{13}{|c|}{ Location } \\
\hline & Hilum & İnferior & Anterior & Posterior & Superior & Lateral & $\begin{array}{l}\text { Hilum } \\
\text { and } \\
\text { İnferior }\end{array}$ & $\begin{array}{l}\text { Hilum } \\
\text { and } \\
\text { Anterior }\end{array}$ & $\begin{array}{l}\text { Anterior } \\
\text { and } \\
\text { Posterior }\end{array}$ & $\begin{array}{l}\text { Medial } \\
\text { and } \\
\text { Anterior }\end{array}$ & $\begin{array}{l}\text { Lateral } \\
\text { and } \\
\text { İnferior }\end{array}$ & $\begin{array}{l}\text { Superior } \\
\text { and } \\
\text { inferior }\end{array}$ & Total \\
\hline 4-9 & 6 & 2 & 6 & & 2 & 2 & - & - & - & - & - & - & 18 \\
\hline 10-19 & 21 & 34 & 5 & 2 & 4 & 2 & - & 2 & - & - & - & - & 70 \\
\hline 20-29 & 79 & 26 & 53 & 4 & 8 & 12 & - & - & - & - & - & - & 182 \\
\hline $30-39$ & 147 & 38 & 54 & 4 & 13 & 5 & 5 & 1 & - & 1 & - & - & 268 \\
\hline $40-49$ & 177 & 76 & 84 & 8 & 7 & 15 & 2 & 7 & 2 & 3 & 2 & - & 383 \\
\hline 50-59 & 182 & 59 & 46 & 4 & 15 & 4 & 1 & 1 & 1 & 1 & - & - & 314 \\
\hline 60-69 & 100 & 57 & 52 & 16 & 6 & 5 & - & 2 & 1 & 1 & 2 & - & 242 \\
\hline 70-79 & 67 & 42 & 33 & 4 & 5 & 2 & - & 5 & - & - & - & - & 158 \\
\hline 80-99 & 22 & 13 & 18 & - & - & - & - & 3 & - & - & - & 2 & 58 \\
\hline Total & 801 & 347 & 351 & 42 & 60 & 47 & 8 & 21 & 4 & 6 & 4 & 2 & 1693 \\
\hline
\end{tabular}

\section{Discussion and conclusion}

The determination and characterization of accessory spleens in terms of clinical practice is considered very important for three main reasons:

(1) Accessory spleens may mimic lymphadenopathy or tumors;

(2) Accessory spleens may become symptomatic due to torsion, rupture, hemorrhage and cyst formation;

(3) When it is essential to extract all functional splenic tissue in certain hematologic diseases, advance determination of surgical approach is important ${ }^{[5,8]}$.

Even though the size of the accessory spleen may vary, many accessory spleens may remain as small nodular masses. Residual spleen tissue may widen in patients who have undergone a splenectomy. When the splenic function starts over, it may lead to the recurrence of certain hematological diseases, such as thrombocytopenic purpura ${ }^{[7,9]}$.

The investigation of an accessory spleen is very important, especially during the preoperative and postoperative stages, to prevent relapse and for therapy planning. Therefore, it is essential to maintain periodic radiological follow-ups regarding the size and morphology of an accessory spleen ${ }^{[7]}$.

It is essential in diagnostic radiology to become aware of and accurately determine congenital variations and anomalies of the spleen because there are other congenital and splenic anomalies that must be differentiated from an accessory spleen ${ }^{[10]}$.

An accessory spleen resembles a lymph node on CT examinations. It is round or oval and its attenuation is identical to that of splenic tissue. When situated in an atypical location, an accessory spleen can mimic an enlarged lymph node as well as a tumor in the adrenal gland, pancreas, stomach, intestine and even in the testis. A mass in the splenic hilum that fails to enhance to the same degree as the splenic parenchyma should not be considered an accessory spleen ${ }^{[3]}$. 
In this unique octennial study of accessory spleen patients, 1693 patients with an accessory spleen were detected. The majority of these patients received frequent follow-ups at periodical intervals to examine the size and radiological morphology of the accessory spleen. Accessory spleen can be found at different locations, but many studies ${ }^{[1-10]}$ describe the condition as primarily located at the splenic hilum, and our study supports this conclusion. Approximately 801 out of 1693 patients demonstrated an accessory spleen, which meant that accessory spleen was present in the splenic hilum of $47.31 \%$ of the total patients. This indicates that it is essential to check the spleen hilum in investigations related to an accessory spleen.

Looking at the distribution of the ages of the patients, we saw no regular age related increase in the number of accessory spleen patients although more patients were found in the 40-49 age range (see Table 3). Because an accessory spleen may develop as a result of an injury, which leads to the rupture of the spleen or results in an abnormality, we assume that the condition is not related to age. Additionally, accessory spleen appeared as a regularly shaped, rounded mass in the CT scans of our patients (see Figures 1-3). This condition can be a significant factor for determining the presence of an accessory spleen.

\section{References}

[1] D'Amico A, Cofalik A, Przeorek C, et al. Role of nuclear medicine imaging in differential diagnosis of accessory spleens in patients after splenectomy. Pol J Radiol. 2012; 77(1): 68-71. PMid:22802870

[2] Dodds WJ, Taylor AJ, Erickson SJ, et al. Radiologic imaging of splenic anomalies. AJR. 1990; 155: 805-810. PMid:2119113 http://dx.doi.org/10.2214/ajr.155.4.2119113

[3] Gayer G, Zissin R, Apter S, et al. CT findings in congenital anomalies of the spleen. Br J Radiol. 2001; 74: $767-772$. PMid:11511506 http://dx.doi.org/10.1259/bjr.74.884.740767

[4] Halpert B, Gyorkey F. Lesions observed in accessory spleens of 311 patients. Am J Clin Pathol. 1959; 32:165-168. PMid:13670140

[5] Mortelé JK, Mortelé B, Silverman GS. CT Features of the Accessory Spleen. AJR. 2004; 183:1653-1657. PMid:15547205 http://dx.doi.org/10.2214/ajr.183.6.01831653

[6] Sohaib SA. CT of splenic disease. Cancer Imaging. 2002: 2. http://dx.doi.org/10.1102/1470-7330.2002.0012.

[7] Tosun A, Çapan MY, Bolat Ş. Splenektomili Olguda Hipertrofik Aksesuar Dalak. The Journal of Academic Geriatrics. 2010; 2(3): 186-188.

[8] Kim SH, Lee JM, Han JK, et al. Intrapancreatic Accessory Spleen: Findings on MR Imaging, CT, US and Scintigraphy, and the Pathologic Analysis. Korean J Radiol. 2008; 9:162-174. PMid:18385564 http://dx.doi.org/10.3348/kjr.2008.9.2.162

[9] Beahrs JR, David H. Stephens EnIarged Accessory Spleens: CT Appearance in Postsplenectomy Patients. AJR. 1980 September; 135:483-486. PMid:6773366 http://dx.doi.org/10.2214/ajr.135.3.483

[10] Vanbeckevoort D, Verswijfel G, Van Hoe L. Congenital disorders of the spleen. In: De Schepper AM, Vanhoenacker F, eds. Medical imaging of the spleen. Berlin, Germany: Springer-Verlag. 2000: 19-28. http://dx.doi.org/10.1007/978-3-642-57045-2_3 